\title{
Immobilization of Pepsin onto Chitosan Silica Nanobeads with Glutaraldehyde as Crosslink Agent
}

\author{
Sari Edi Cahyaningrum ${ }^{1 *}$, Maria Monica Sianita ${ }^{1}$ \\ ${ }^{1}$ Department of Chemistry, Faculty Mathematics and Natural Science, State University of \\ Surabaya, Jl. Ketintang Surabaya 60231, Indonesia
}

Received: 1st July 2014; Revised: 3rd September 2014; Accepted: 3rd September 2014

\begin{abstract}
Glutaraldehyde crosslinked chitosan - silica nanobeads have been used as a support in the immobilization process of pepsin. The effect of $\mathrm{pH}$, pepsin concentration, and temperature on the characteristics of both free and immobilized pepsin had been investigated in this study. The results showed that the immobilized pepsin has wider $\mathrm{pH}$ range, better capacity, performance and stability to high temperatures compared with those of free pepsin. The immobilized pepsin can be used for 8 to 10 times at which the activity remains $20 \%$, whereas the free pepsin can only be used once. These results suggested promising applications of immobilized enzyme as biocatalyst. (C) 2014 BCREC UNDIP. All rights reserved.
\end{abstract}

Keywords: immobilized pepsin; chitosan; silica; glutaraldehyde crosslinker

How to Cite: Cahyaningrum, S.E., Sianita, M.M. (2014). Immobilization of Pepsin onto Chitosan Silica Nanobeads with Glutaraldehyde as Crosslink Agent. Bulletin of Chemical Reaction Engineering \& Catalysis, 9 (3): 263-269. (doi:10.9767/bcrec.9.3.7060.263-269)

Permalink/DOI: http://dx.doi.org/10.9767/bcrec.9.3.7060.263-269

\section{Introduction}

The unique characteristics of enzymes, such their catalytic ability and specificity on substrates have driven the utilizations of enzymes in many applications. Enzymes are widely used in industries, such as in food and beverages, milk, cosmetics, pharmaceutics, paper, leather, and detergents, which $59 \%$ of them use protease. Pepsin is one of proteases [1-3]. Pepsin can break protein into water soluble fragments, called pepton. Pepsin are often used as rennin substituent in certain cheese production $[4,5]$. In leather industry pepsin is used to remove oil and fat from the leather to make it softer.

Chemical synthesis in laboratories and industries involving pepsin often conducted by

\footnotetext{
* Coresponding Author .

Email: muhacahya@yahoo.co.id

Telp.+62-31-8298761, Fax.+62-31-8298761
}

treated the substrates with enzymes that soluble in water so that they were mixed each other. The usage of soluble enzymes have some drawbacks. They are difficult to be separated from the substrates and products. The separation process was usually done by heating or changing the acidity $(\mathrm{pH})$ that can denaturate the enzyme. Soluble enzymes are also unstable so it is difficult to be reused them after reaction. Nowadays most reseachers use immobilized enzymes in industrial bioprocesses [6] by binding the enzymes with supports that are not dissolved in water. Those enzymes can form ionic or covalent bond, crosslinking, or entrapped on the supports [7]. The immobilized enzymes enable the separation of the enzyme catalysts easily from the mixtures so that they can be reused and can decrease the cost of the enzymes purification [8]. There are three of the most common methods used to immobilized en- 
zymes, i.e. physical adsorption, entrapment (encapsulation) and cross linking, or covalently binding to a support [6,9]. A water insoluble polysaccharides, such as cellulose, starch, agarose and chitosan and proteins (gelatin and albumin), have been widely used as supports for immobilizing enzymes [10,11]. Some supports that can be used for immobilized enzymes are silica alumina [12,13], alginate [14], silica [15], chitosan bead-glutaraldehyde [16], chitosan silica-metal ion [17] and other synthetic and natural polymers.

Chitosan is one of natural polymer derived by deacetylation of chitin. When the $\mathrm{pH}$ of the solution is lower than its $\mathrm{pKa}$, chitosan acts as a water soluble polyelectrolyte. However, when the $\mathrm{pH}$ is higher than its $\mathrm{pKa}$, chitosan is not soluble in water. Chitosan has excellent film forming ability, biocompatibility, nontoxicity, high mechanical strength, cheapness and a susceptibility to chemical modifications [18]. Previous research on the use of metals ion $\mathrm{C} \mathrm{Ca}^{2+}$, $\mathrm{Mg}^{2+}, \mathrm{Zn}^{2+}$, and $\mathrm{Cu}^{2+}$ ) as crosslinking agents on chitosan bead to immobilized papain, showed a slight decrease of enzyme activity and limited reusability when $\mathrm{Ca}^{2+}$ and $\mathrm{Mg}^{2+}$ were used as crosslinking agents. In contrary, significant decrease of immobilized enzyme activity and high reusability were observed when using $\mathrm{Zn}^{2+}$ and $\mathrm{Cu}^{2+}$ were used as crosslinking agents [19].

The objectives of the present study are to evaluate the immobilization processes of pepsin on chitosan - glutaraldehyde - silica supports and to evaluate the activity of the immobilized pepsin as affected by $\mathrm{pH}$ and temperature, measuring the thermal stability and reusability of the enzyme.

\section{Materials and Methods}

\subsection{Chemicals}

Materials used in this research are Porcine pepsin (E.C. 3.4.23.1), chitosan with degree of deacetylation of $85 \%$, glutaraldehyde, tyrosin, Bovine serum albumin (BSA, molecular mass= $67000 \mathrm{Da})$, Silica gel (100-200 mesh size) purchased from Sigma Chemical Co., St Louis, MO, USA, sodium citrate, sodium hydroxide, hydrochloric acid, citric acid, acetic acid glacial, and trichloroacetic acid (TCA) were purchased from Merck AG, Darmstadt, Germany. Demineral water was purchased from PT Dianum Indonesia. All chemical are pro analysis grade (p.a). This research used immobilized pepsin in chitosan silica using glutaraldehyde as a crosslinking agent.

\subsection{Preparation of Chitosan-Silica Supports using Glutaraldehyde Crosslinker}

Chitosan-silica nanobeads supports were prepared by dissolving chitosan powder into $2 \%$ of acetic acid in magnetic stirred the solution for two hours. The chitosan solution was then mixed with silica (1:2) and followed by vigorous stirring to obtain homogeneity. The chitosansilica solution was then added to $2 \mathrm{M}$ of sodium hydroxide solution containing ethanol droplet to form chitosan silica nanobeads. The substance obtained was filtered and evaporated at room temperature to achieve rigidity. Then, it was immersed in $5.5 \%$ glutaraldehyde $(\mathrm{v} / \mathrm{v})$ for 24 hours. The supported chitosan silica nanobeads with glutaraldehyde crosslinker was neutralized using demineralized water, filtered, and dried at room temperature. The support was analyzed using Fourier Transform InfraRed Spectrophotometer using wave number from 400 to $4000 \mathrm{~cm}^{-1}$.

\subsection{Bradford Method for Protein Content Determination}

Concentration of soluble protein was determined using Bradford protein assay in which a differential color change of dye occurs in response to various concentration of protein. The absorbance maximum for an acidic solution of Coomassie R Blue G-250 dye shifts at $595 \mathrm{~nm}$ when binding to protein occurs. The Coomassie R Blue G-250 dye binds primarily basic and aromatic amino acid residues especially arginine. Protein concentration was determined using Bradford dye binding assay [20] with BSA as standard. The sample $(25 \mathrm{\mu l})$ was mixed with $750 \mu \mathrm{l}$ Bradford reagent and the absorbance at $595 \mathrm{~nm}$ was measured after $15 \mathrm{~min}$ of incubation at $25^{\circ} \mathrm{C}$. Calculation of the protein concentration was done using the BSA calibration curve in the range of $0-0.9 \mathrm{mg} / \mathrm{ml}$.

\subsection{Determination of the Activity of Pep- $\sin$}

A $0.5 \mathrm{ml}$ of casein at a concentration of 10 $\mathrm{mg} / \mathrm{ml}$ was put into a test tube, added by $2.5 \mathrm{ml}$ of buffer phosphate at $\mathrm{pH} 4$, while $0.25 \mathrm{ml}$ of pepsin was put into another test tube. Both test tubes were preincubated at $45{ }^{\circ} \mathrm{C}$ for 10 minutes. After preincubated the free pepsin has been put into the tube containing buffer and casein, then incubated at $45{ }^{\circ} \mathrm{C}$ for 10 minutes. After 10 minutes the enzymatic reaction has been stopped by adding $1 \mathrm{ml}$ of TCA $10 \%$. The sample, chitosan silica 
nanobead support was centrifuged at 3000 RPM for 5 minutes. The filtrate was then separated from the residu and analyzed using Spectrophotometer UV-vis at $\lambda 280 \mathrm{~nm}$.

\subsection{The Effect of pH on Immobilized Pep- sin Process}

A 0.1 gram of chitosan silica nanobeads support was put into acontainer then added by $20 \mathrm{mg} / \mathrm{ml}$ of pepsin until $10 \mathrm{ml}$ then mixed in a shaker waterbath for 12 hours. The procedure was repeated using different $\mathrm{pH}$ varied from 4 to 8 . After 12 hours the residu was filtered off using $0.45 \mu \mathrm{m}$ of filter paper. The filtrate was analyzed using Bradford method [20] and the concentration of protein was determined using spectrophotometer UV-vis. The number of immobilized pepsin was calculated based on the differences between the initial concentration and the concentration of pepsin remained in the solution.

\subsection{The Concentration Effect of Pepsin on Immobilized Pepsin Process}

A 0.1 gram of chitosan silica nanobeads support was put into a container then added by pepsin varied from $5 \mathrm{mg} / \mathrm{ml}$ to $35 \mathrm{mg} / \mathrm{ml}$ at $\mathrm{pH}$ 4. The volume of each solution was $10 \mathrm{ml}$. Sample was mixed using shaker water bath for 12 hours, then filtered using $0.45 \mu \mathrm{m}$ filter paper. The filtrate was analyzed using Bradford method [20] and the concentration of protein was determined using spectrophotometer UV-vis. The number of immobilized pepsin was calculated based on the differences between the initial concentration and the concentration of pepsin remained in the solution.

\subsection{The Temperature Effect on the Activ- ity of Free and Immobilized Pepsin}

Pepsin was treated with the substrate at buffer $\mathrm{pH} 4$ and allowed to stand for 10 minutes using different temperature ranged from $30{ }^{\circ} \mathrm{C}$ to $80{ }^{\circ} \mathrm{C}$. After 10 minutes the reaction was stopped by adding $1 \mathrm{ml}$ of $10 \%$ TCA, then the solution was centrifuged. The filtrate was analyzed using Spectrophotometer $\mathrm{UV}$-vis at $\lambda 280 \mathrm{~nm}$.

\subsection{The Thermal Stability of Free and Im- mobilized Pepsin}

The thermal stability of both free and immobilized pepsin has been observed by incubating them at temperature variation from $30{ }^{\circ} \mathrm{C}$ to 80 ${ }^{0} \mathrm{C}$ for 2 hours. After that each enzyme was treated for determining effect of temperature as describe in procedure 2.6 .

\subsection{The Enzymatic Kinetic of Free and Im- mobilized Pepsin}

Both free and immobilized pepsin were used separately for kinetic study using casein as a substrate with concentrations varied from 5 to $50 \mathrm{mg} / \mathrm{ml}$ at buffer $\mathrm{pH} 4$, temperature of $45 \mathrm{oC}$ for 10 minutes. After exposure the reaction was stopped by adding $1 \mathrm{ml}$ of TCA $10 \%$ and followed by centrifugation. The filtrate was analyzed using Spectrophotometer UV-vis at $\mathrm{A} 280$ $\mathrm{nm}$. The kinetic enzymatic of free and immobilized pepsin was examined using LineweaverBurk equation.

\subsection{The Reusability of Immobilized Pep- $\sin$}

This test was conducted only for the immobilized pepsin as the free pepsin can only be used once. About 0.1 gram of immobilized pepsin was tested with $1 \mathrm{ml}$ of casein substrate of $10 \mathrm{mg} / \mathrm{ml}$. Then, $2.5 \mathrm{ml}$ of buffer phosphate at $\mathrm{pH} 4$ was added and temperature was kept at $45{ }^{\circ} \mathrm{C}$ for 10 minutes. After exposure the reaction was stopped by adding $1 \mathrm{ml}$ of TCA $10 \%$ and followed by centrifugation and filtration. The filtrate was analyzed using Spectrophotometer UV-vis at $\lambda 280 \mathrm{~nm}$. The residue was washed using $0.05 \mathrm{M}$ of $\mathrm{HCl}$ for removal of the substrate remained. The activity of the immobilized pepsin was re-examined using new casein substrate, and the procedure was repeated until low activity of the immobilized pepsin was obtained.

\section{Results and Discussion}

Pepsin has been used especially in the food industry as a milk coagulant to make cheese. Many studies on immobilization pepsin have been reported [4,11,12]. Analysis of functional group of chitosan silica nanobeads glutaraldehyde support showed that there are absorption at the wave number of $1574 \mathrm{~cm}^{-1}$ (C-N vibration) and at $1612 \mathrm{~cm}^{-1}(\mathrm{C}=\mathrm{N}$ vibration $)$ which represented the binding of chitosan-silica with the glutaraldehyde crosslinker and the binding of amino-pepsin group with glutaraldehyde, respectively

\subsection{The Effect of pH on Immobilized Pro- cess}

Figure 1 shows the effect of $\mathrm{pH}$ of immobilization process of pepsin on chitosan silica glutaraldehyde. The number of immobilized pepsin was proportional to the 
increasing of $\mathrm{pH}$. On the $\mathrm{pH}$ closed to the isoelectric point, about 4.5 , the number of immobilized pepsin increased sharply and reached the optimum condition at the $\mathrm{pH}$ 5. On a $\mathrm{pH}$ above the isoelectric point, the enzyme was on $-\mathrm{NH}_{3}{ }^{+}$and $-\mathrm{COO}$. This condition allowed the pepsin to interact with the crosslinker at two different poles that produce the maximum interaction.

\subsection{The Immobilized Capacity}

Figure 2 shows the effect of pepsin concentration toward the immobilized capacity. The number of immobilized pepsin increased as the concentration increased, and reached the equilibrium at $25 \mathrm{mg} / \mathrm{ml}$. It was assumed that all active sites of the support has been saturated with the pepsin.

The capacity of the immobilized pepsin on the support has been analyzed using Langmuir isoterm equation:

$$
\frac{[\mathrm{Ce}]}{[Q]}=\frac{1}{k[Q] \max }+\frac{[\mathrm{Ce}]}{[Q] \max }
$$

where [Ce] and [Q] represent the equilibrium concentration of pepsin and the adsorbed

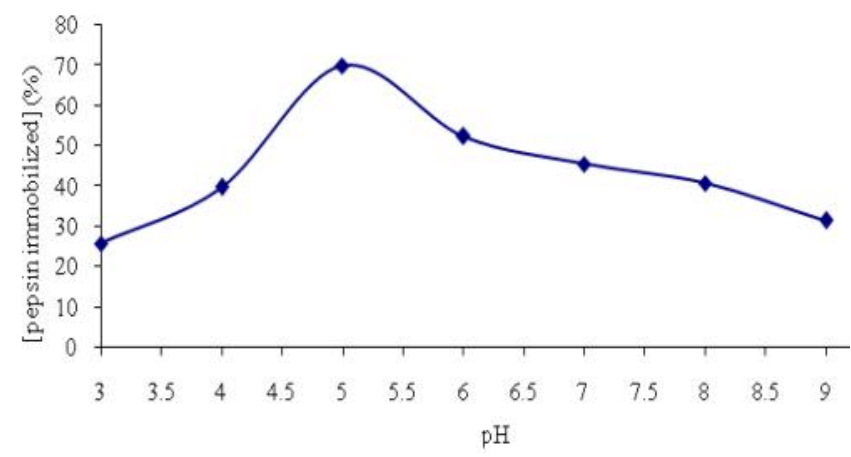

Figure 1. Effect of $\mathrm{pH}$ to the immobilized pepsin

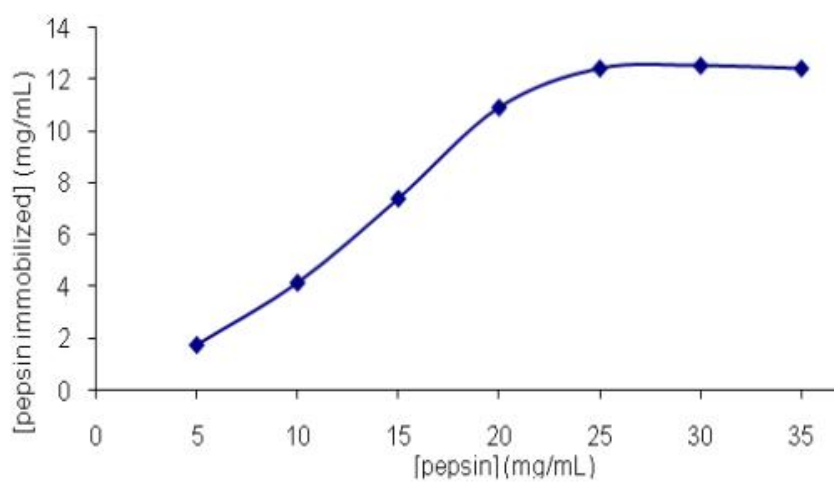

Figure 2. Effect of pepsin concentration on immobilized capacity activity per gram weight of support, respectively; $[Q]$ max represents the maximum pepsin activity adsorbed per gram weight of support; $k$ is the adsorption-desorption equilibrium constant related to the binding energy (E). Data of Langmuir isotherm equation showed the value of Q[max] was $56.10^{-4} \mathrm{~mol} / \mathrm{g}$; $\mathrm{k}$ was 785432,939 (mol/l); E was 54,87 kJ/mol; $\mathrm{R}^{2}=0,9981$.

\subsection{The Effect of pH on the Activity of Free and Immobilized Pepsin}

The activity of immobilized pepsin has been affected by $\mathrm{pH}$. Figure 3 shows the effect of $\mathrm{pH}$ toward the enzymatic activity of both free and immobilized pepsin. The activity of free pepsin reached the maximum value at $\mathrm{pH} 4$, then going down and decreased sharply at $\mathrm{pH} 7$ to 8 , whereas the enzymatic activity of the immobilized pepsin reached the maximum value at $\mathrm{pH}$ 4 and degrees slowly to $\mathrm{pH}$ until 8 . This fact showed the advantage of using immobilized pepsin in laboratory and industrial processes

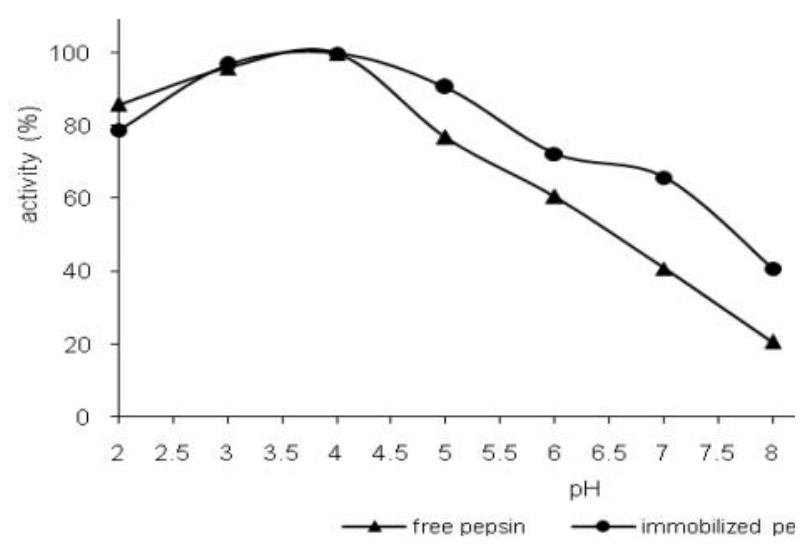

Figure 3. Effect of $\mathrm{pH}$ on activity of free pepsin and immobilized pepsin

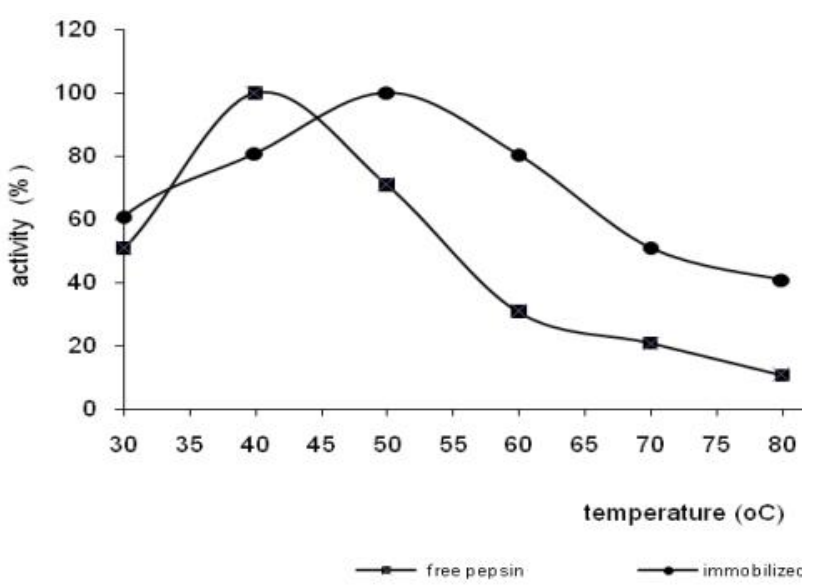

Figure 4. Effect of temperature on the activity of free and immobilized pepsin 
because of its flexibility.

\subsection{The Effect of Temperature on Activi- ties of Free and Immobilized Pepsin}

Temperature has a great effect on the enzymatic reaction of pepsin. Figure 4 showed that the free pepsin reached the maximum activity at $40{ }^{\circ} \mathrm{C}$, then decreased sharply as the temperature increased. Whereas the activity of immobilized pepsin reached the maximum activity at $50{ }^{\circ} \mathrm{C}$, then decreased gradually. This facts showed that the immobilized pepsin is more stable in high temperature because its supporting material protected the immobilized pepsin from denaturation process. Most of the industrial process need high temperature, so the immobilized pepsin is more readily to be used.

\subsection{The Thermal Stability of Free and Im- mobilized Pepsin}

One parameter to determine the quality of the immobilized enzyme is thermal stability of the enzyme produced. The pepsin has been exposed to the temperature of $30{ }^{\circ} \mathrm{C}$ to $70{ }^{\circ} \mathrm{C}$ for two hours, before treated with substrate. Figure 5 showed that the immobilized pepsin has better thermal stability than the free pepsin. During the immobilization process the active site of pepsin form the covalent coordination bonds with the active site of the supports. The process involving this covalent bond produces enzyme that has good thermal stability, but its bonding may not be overweening because it causes degradation of very sharp activity. It can be expected that the immobilization process will improve the characteristic of pepsin without decreasing its activity sharply. Immo-

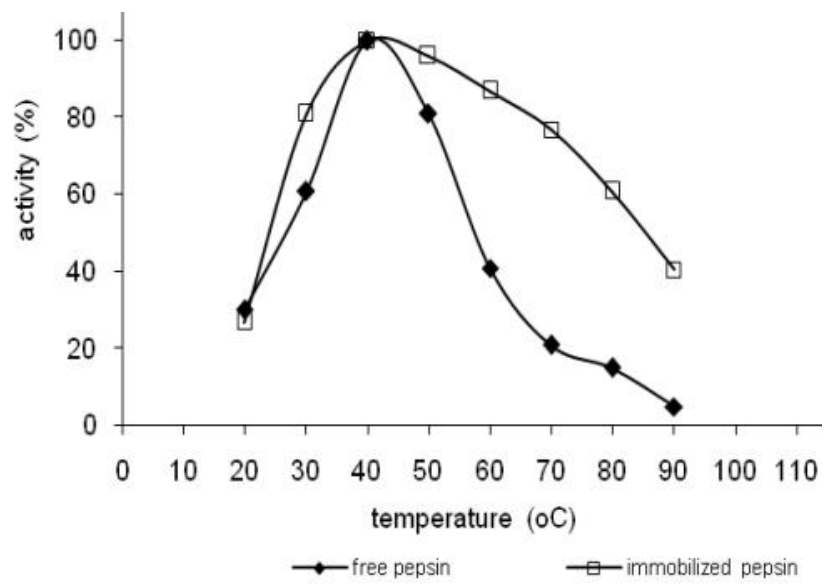

Figure 5. The thermal stability of free and immobilized pepsin bilization pepsin on chitosan silica glutaraldehyde caused increasing in pepsin rigidity which is commonly reflected by stability towards denaturation by raising the temperature.

\subsection{The Kinetic Parameter of Pepsin}

The kinetic parameters that changed due to the immobilization process are KM and VMax, which reflect the affinity of an enzyme on a substrate. The smaller the value of KM shows the higher affinity of an enzyme on a substrate, and vice versa. Jiamin [16] reported that the immobilization of tripsin increased the value of KM, but decreased the value of VMax. Data presented on Table 1 showed that the immobilized pepsin has greater values of KM than free pepsin. The supports used for immobilied the pepsin blocks it from interacted with the substrate so the affinity decreased and the VMax increased. It is assumed that on immobilized pepsin there are conformation changes because of the bonding between the active sites of pepsin with those of glutaraldehyde and chitosan silica nanobeads.

Table 1. Data of kinetics parameter of free and immobilized pepsin

\begin{tabular}{ccc}
\hline \multicolumn{3}{c}{ The value of $\mathrm{K}_{\mathrm{M}}$ and $\mathrm{V}_{\mathrm{Max}}$} \\
\hline Enzyme & $\mathrm{KM}(\mathrm{mg} / \mathrm{ml})$ & $\mathrm{V} \max (\mathrm{U} / \mathrm{mg})$ \\
\hline Free pepsin & $4.158 .10^{-2}$ & $5.143 .10^{-2}$ \\
$\begin{array}{c}\text { Immobilized } \\
\text { pepsin }\end{array}$ & $6.282 .10^{-2}$ & $4.4187 .10^{-2}$ \\
\hline
\end{tabular}

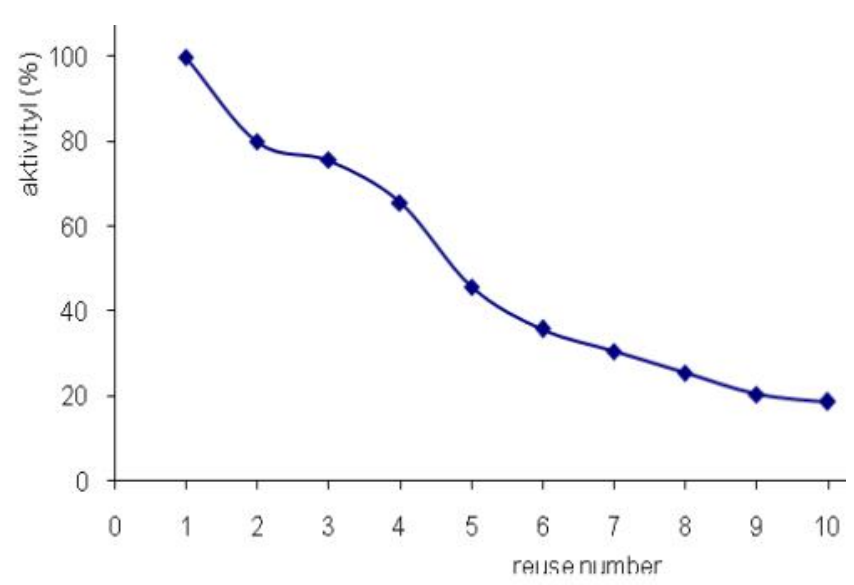

Figure 6. The reuse number of immobilized pepsin 


\subsection{The Reusability of the Immobilized Pepsin}

Another parameter of enzyme quality is its ability to be reused. The immobilized enzyme cannot be mixed with the substrate or the product so at the end of the process the enzyme can be re-obtained easily and can be used multiple times. The more frequent it can be reused, the better its quality. The quality of the immobilized pepsin produced in this research has been tested and the results are presented on Figure 6. The graph showed that the immobilized pepsin can be reused for 8 to 10 times. The pepsin immobilized retained a specific activity of $81 \%$ after first reuse and the activity still remains $20 \%$ after used for 10 times. This phenomena brings an advantage over using free pepsin.

\section{Conclusions}

Based on the results, it can be concluded that the immobilized pepsin on chitosan silica nanobeads supports with glutaraldehyde as cross-linker reach the optimum condition at $\mathrm{pH}$ of 5, with the immobilized capacity of 56.10-4 $\mathrm{mol} / \mathrm{g}$. The $\mathrm{NH}_{2}$ group has more dominant role in the process of enzyme than the $\mathrm{OH}$ group. As a cross-linker, glutaraldehyde increases the supports stability so that the immobilized pepsin produced has higher temperature stability, wider $\mathrm{pH}$ range, and more reusability compared with those of free pepsin. Although the performance activity of the immobilized pepsin decreased with the number of usages, it still can be used for 8-10 times with specific activity $20 \%$ after 10 times use so its total activity is higher than that of free pepsin. This immobilized enzyme characteristics suggests wider applications in industrial field.

\section{References}

[1] Ahmed, S.A.A. (2003). Biochemical Studies on Some Enzymes Used in Industry. PhD Thesis. Cario University, Faculty of Agriculture, Cairo: 109-135.

[2] Magda, A. E., Maysa, E.M., Ali, H.T. (2009). Efficient Immobilization of Milk Clotting Enzyme produced by Bacillus sphaericus. Polish Journal of Food and Nutrition Sciences, 59: 167-172

[3] Magda, A.E., Moharam, M.A., Ali, H.T (2007). Purification and Characterization of Milk Clotting Activity by Bacillus sphaericus. Egypt. Journal Applied Sciences Research, 3: 695-699.
[4] Frydlova, J., Kucerova, Z., Ticha, M. (2004). Affinity Chromatography of Porcine Pepsin and Pepsinogen using Immobilized Ligand Derived from the Specific Substrate for this Enzyme. Journal of Chromatography B, 800: 109-114.

[5] Altum, G.D., Senay, A.C., (2007). Immobilization Of Pepsin On Chitosan Beads. Food Chemistry. 100: 964-971.

[6] Esawy, M.A., Combet, B. Y. (2006). Immobilization of Bacillus licheniformis 5A1 Milk Clotting Enzymes and Characterization of its Enzymme Properties. World. Journal Microbiology Biotechnology. 22: 197-200.

[7] Orrego, C.E., Salgado, N., Valencia, J.S., Giraldo, G.I., Cardona, C.A. (2010). Novel Chitosan Membranes as Support for Lipases Immobilization: Characterization Aspects. Carbohydrates Polymer. 79: 9-16.

[8] Malmiri, J.H., Jahanian, G.A.M., Berenjian, A. (2012). Potential Applications of Chitosan NanoparticlesAs Novel Support In Enzymee Immobilization. American Journal of Biochemistry and Biotechnology. 8 (4): 203-219.

[9] Chiou, S. H., Wu, W.T., (2004). Immobilization of Candida rugosa Lipase on Chitosan with Activation of the Hydroxyl Groups. Biomaterials, 25: 197-204.

[10] Chao, L., Langen, L.V., Sheldon, R.A., (2003). Immobilization Enzymes: Carrier-bound or Carrier Free? Current Opinion in Biotechnology, 14: 387-394.

[11] Liu, W., Wang, L., Jiang, R. (2012). Specific Enzyme Immobilization Approaches and Their Application with Nanomaterials. Top Catalysis 55: 1146-1156.

[12] Ticu, F.L., Marko, D.V., Froidevaux, R., Huma, A., Artenie, V., Guillochon, D. (2005). Use Of Protease - Modified - Alumina Complex To Design A Continuous Stirred Tank Reactor For Producing Bioactive Hydrolysates. Process Biochemistry, 40 (8): 2841-2848

[13] Godjevargova, T., Nenkova, R., Konsulov, V. (2006). Immobilization of Glucode Oxidase by Acrylonitrile Copolymer Coated Silica Supports. Journal Molecules Catalysis B-Enzyme. 38: $59-64$

[14] Devi, B., Unni, B.G., Wann, S.B., Samanta, R. (2012). Immobilization of Partially Purified Alpha Amylase Enzyme Produced by Soil Born Bacillus sp. Advances in Applied Science Research. 3(5): 2739-2744.

[15] Valentina, N., Michela, S., Elena, G. (2011). B-Galactosidase Entrapment in Silica Gel Matrices for a More Effective Treatment of Lactose Intolerance. Journal of Molecular Catalysis B: Enzyme. 143: 62-72 
[16] Chen, H., Zang, Q., Dang, Y., Shu, G. (2013). The Effect of Glutaraldehyde Cross-Linking in the Enzyme Activity of Immobilized B- Galactosidase on Chitosan Beads. Advanced Journal of Food Science and Technology. 5(7): 932-925.

[17] Wu, J., Luang, M., Lhao, Z. (2006). Trypsin Imobilization by Direct Adsorption on Metel Ion Chelated Macroporous Chitosan Silica Gel Beads. International Journal of Biological Macromolecules. 39: 185-191.

[18] Laing, Z., Sang, J.Li., Cao, C., Wang, G. (2006). Preparation of Urease Immobilized onto Glutaraldehyde Cross-linked Chitosan Bead. Journal Qindai Univ. Science. Technology, 27: 123-126.
[19] Cahyaningrum, S.E., Narsito, Santoso, S.J., Agustini, R (2009). Involvement Of Metal Cation Crosslink Agent In Papain Immobilization On Chitosan. PhD Dissertation, Dept. of Chemistry. Gajah Mada University. Indonesia.

[20] Bradford, M.M. (1976). A Rapid And Sensitive Method for Quantitation of Microgram Quantities of Protein Utilizing the Principle of Protein Dye Binding. Analytical Biochemistry. 72: 248-248. 